In the morning a company was chosen to explore the retreat of the fugitives, and to bring them forth. They followed the winding path with some difficulty, until it was closed by a huge rock, which had fallen from the height above. They found their way around it, and on the further side, they saw the bow of Har-lo-wa-rah, and a portion of the blanket of Chi-oc-o-ma. The rock which overhung the cave, had fallen during the terrible concussion of the preceding night, and had instantly buried the Indian outlaw and his bride.

The tribes to this day believe it to have been a direct interposition of providence, in punishing by a violent death the guilty pair. Many years have elapsed, yet a sense of awe steals over the hardiest warrior, as he passes the place where this catastrophe happened, similar to that which is felt by the devout Christian as he stands on Mount Sinai, and feels that on the same rocks have been marked the footsteps of the Almighty; and that the same echoes that answer to his voice, have reverberated to the sound of the thunders of his presence and power.Western Magazine, May, 1846.

\title{
NICOLAS BOILVIN, INDIAN AGENT
}

Nicolas Boilvin spent twenty years of his life on the Upper Mississippi as an officer of the United States government-first as assistant, or subagent, on the Des Moines river, and later as Indian agent, with his home and station at Prairie du Chien. Although his early life has never been fully revealed, Boilvin asserted repeatedly that he had spent more than forty years among the Indians.

Born in Canada in 1761, he arrived, at the age of thirteen, in that part of the Illinois country which later became Missouri. At the close of the American Revolution he was back in Montreal, but in 1783 was employed by Patrick Sinclair, who had been a high ranking British officer in the Indian country, to take charge of his farm near Detroit. On reaching that past, Boilvin decided to go further west.-P. L. Scanlan, in the Wiscontin Magazine of History. 
Copyright of Annals of Iowa is the property of State of Iowa, by \& through the State Historical Society of Iowa and its content may not be copied or emailed to multiple sites or posted to a listserv without the copyright holder's express written permission. However, users may print, download, or email articles for individual use. 